\title{
Fast recession of the northern Larsen Ice Shelf monitored by space images
}

\author{
PEDRo SKVARCA \\ Instituto Antártico Argentino, Cerrito 1248, 1010 Buenos Aires, Argentina.
}

\begin{abstract}
The rapid retreat and disintegration of the Larsen Ice Shelf sector extending north of Seal Nunataks $\left(65^{\circ} \mathrm{S}\right)$, documented from the mid 1970s onwards by remote sensing, is presented and related to the Antarctic Peninsula climatic warming recorded over several past decades. A 1975 KOSMOS satellite photograph and a series of LANDSAT MSS and TM images taken in 1978, 1979, 1986, 1988 and 1989 were used to monitor the retreat of the ice shelf between Seal Nunataks and Prince Gustav Channel. The ice shelf has decreased by more than 30\% during the period 1975-89 within the Christensen Island to Cape Longing region. Measurements of the ice front position carried out in the field during late 1991 indicate that the recession between Lindenberg Island and Sobral Peninsula is still continuing, in some places at a rate of up to $2.5 \mathrm{~km} \mathrm{a}^{-1}$.
\end{abstract}

\section{INTRODUCTION}

The Larsen Ice Shelf sector north of Robertson Island (Fig. 1) represents the northernmost shelf ice in the Antarctic. In this region mean annual isotherms, normalized at sea-level, range from about $-8^{\circ} \mathrm{C}$ to $-5^{\circ} \mathrm{C}$ (Reynolds, 1981). This ice shelf, therefore, is as sensitive to atmospheric warming and thus vulnerable to break-up as other ice shelves in the Antarctic Peninsula, such as the Wordie Ice Shelf (Doake and Vaughan, 1991).

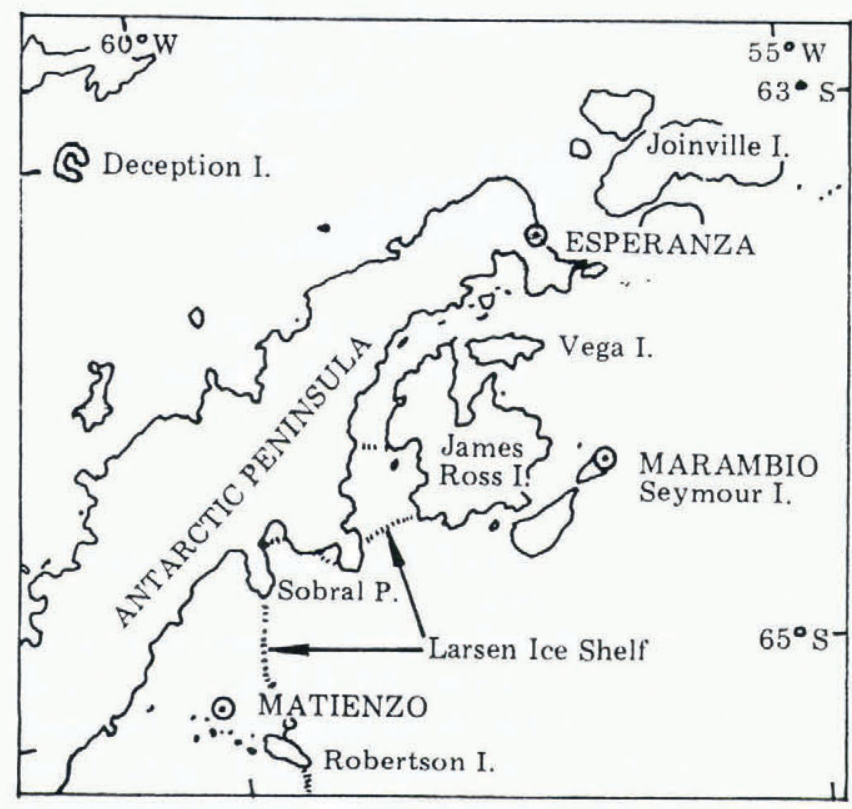

Fig. 1. Location map of northern Larsen Ice Shelf and nearby stations.
Until the late 1940s the Larsen Ice Shelf front extended from Cape Foster, the southernmost tip of James Ross Island, and beyond Cape Longing to Robertson Island (Koerner, 1964). The recession history since then until 1969, as well as the evidence of further retreat observed by British Antarctic Survey (BAS) field parties in 1980-81, have already been described by Doake (1982); the same author also predicted that a retreat of up to $1 \mathrm{~km} \mathrm{a}^{-1}$ would probably continue.

The topographic map Series BAS 250 Sheet SQ 21-22/ 1 (Edition 1 - D.O.S. 1974), vaguely shows the ice shelf front position in 30 December 1969. No substantial changes have taken place between Cape Longing and Lindenberg Island during the period 1969-75.

\section{REGESSION STUDY FROM SATELLITE DATA}

The first accurate position of the ice shelf front, stretching from Cape Longing to Robertson Island, is documented from space by an excellent cloud-free photograph, obtained by a KOSMOS satellite on 3 October 1975 (Fig. 2). Since this photograph was taken in early Antarctic spring, a large extension of fast ice attached to the ice front may be observed in the Weddell Sea. Nevertheless, the seaward edge of the ice shelf is clearly visible along nearly the entire $70 \mathrm{~km}$ extent from Robertson Island to Longing Gap. Rifts parallel to the ice front can be observed for about $30 \mathrm{~km}$ north of Lindenberg Island, indicating probable future calving events that were confirmed by later Landsat images.

Recent high resolution Landsat TM images became available for this study through the Scientific Committee on Antarctic Research (SCAR) cooperative acquisition project, initiated in 1987 to monitor changes occurring 


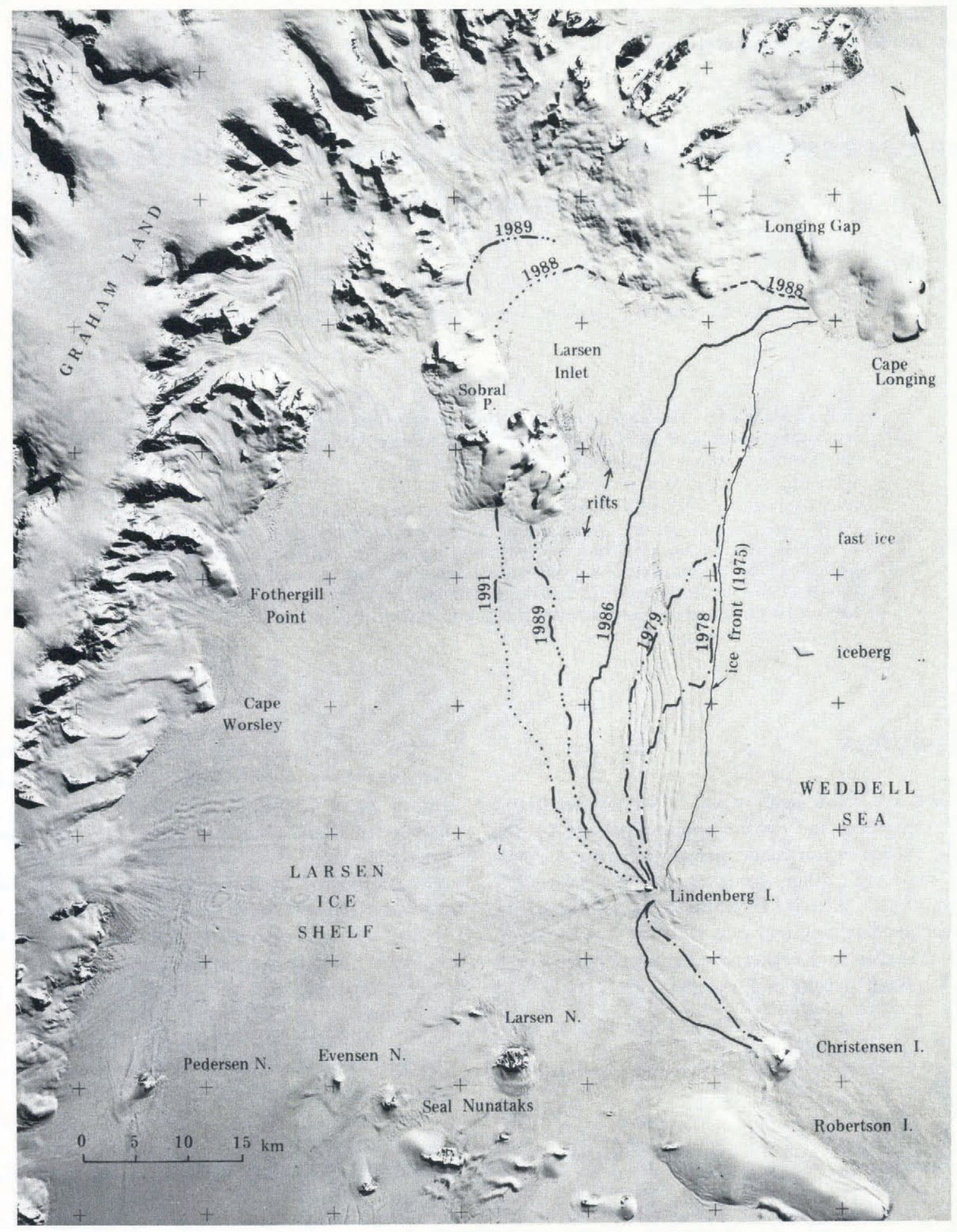

Fig. 2. Section of the KOSMOS satellite photograph, (Film no. 1064, Frame no. 0596), taken by KATE-200 (focal length: $200.360 \mathrm{~mm}$ ) on 3 October 1975, with superimposed sketch of ice front positions from 1975 to 1991 (published by courtesy of SOJUZKARTA).

within dynamic areas of Antarctic coastal regions (Ferrigno and others, 1990). These images were compared with earlier Landsat MSS baseline data acquired after the mid 1970s and with the 1975 KOSMOS photograph.

The 1975 KOSMOS photograph, the Landsat MSS (band-7) images of 1978 and 1979, and the Landsat TM (band-4) images of 1986, 1988 and 1989 (only photographic products) were enlarged to a $\sim 1: 500000$ scale in order to define more accurately sequential positions of the seaward edge of the ice shelf. The positions are plotted on Figure 2 for the recession study.

Comparison of the 1975 photograph with the Landsat MSS images of 4 November 1978 (ID 30244-12182 and 30244-12184) shows that the ice front position remained invariable to about $35 \mathrm{~km}$ south of Cape Longing. From this point towards Lindenberg Island the front retreated a maximum of $6 \mathrm{~km}$, and from Lindenberg to Christensen Islands an average of $2 \mathrm{~km}$; from November 1978 until 20 February 1979 (Image ID 30352-12180), i.e. during the 


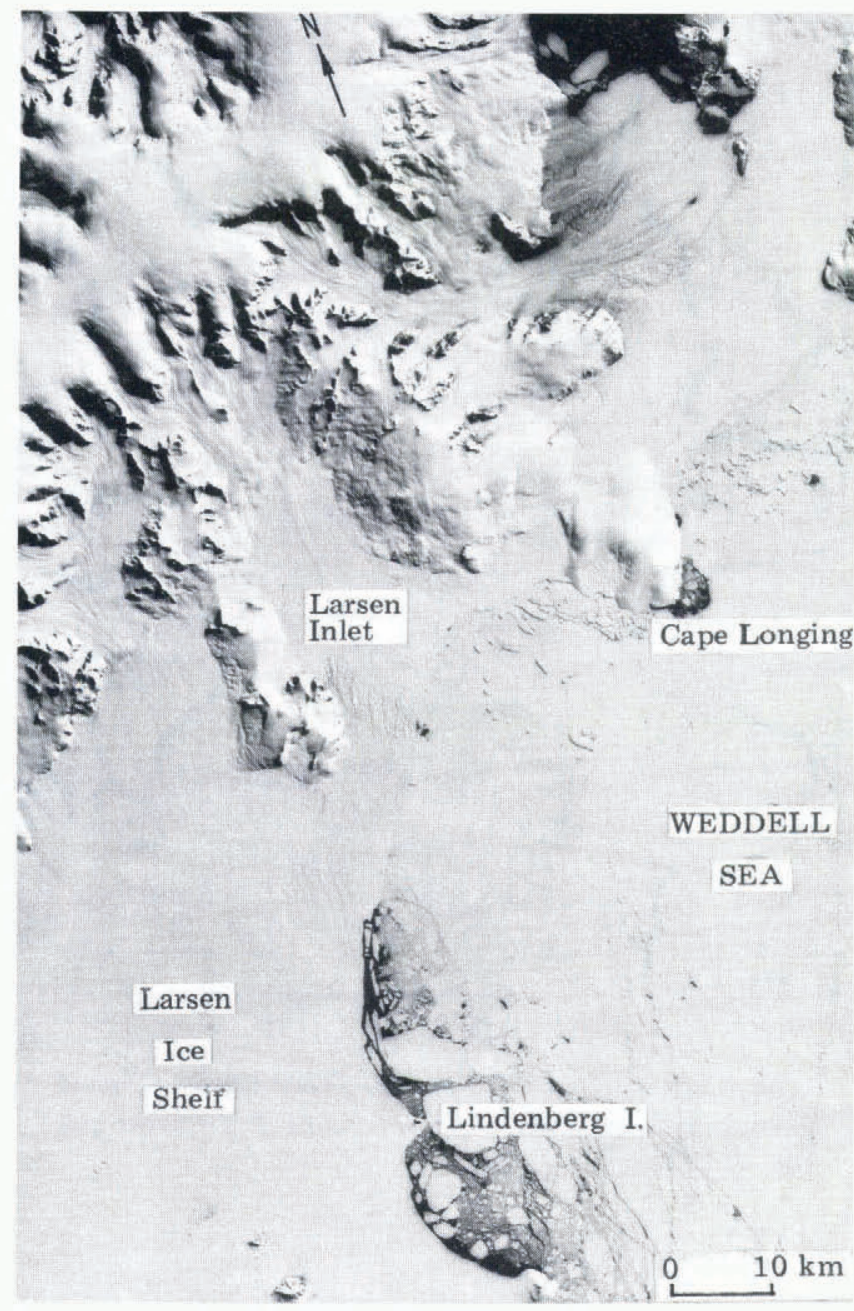

Fig. 3. Portion of Landsat TM image (ID 50730-122954) showing the ice front position on 1 March 1986 (Reproduced by permission of EOSAT).

Antarctic summer, the calving process continued at a much faster rate, but only the $32 \mathrm{~km}$ north of Lindenberg Island were affected. The position of the ice-shelf edge in front of the Larsen Inlet underwent almost no change from 1975 to 1979 . But the rifts extending from both sides of Sobral Peninsula towards the ice front are clearly visible on all images until 1986.

The Landsat TM image of 1 March 1986 (Fig. 3) reveals a considerable retreat since 1979 , especially within the area south of Larsen Inlet (Fig. 2), where the ice front receded between 7 and $8 \mathrm{~km}$. A comparison of the 1975 and 1986 ice front positions shows that an average retreat of $\sim 10 \mathrm{~km}$ took place within this 10.5 year period, giving an approximate recession rate of $1 \mathrm{~km} \mathrm{a}^{-1}$, as suggested previously (Doake, 1982). Within this time interval the ice shelf area has decreased by approximately $540 \mathrm{~km}^{2}$. But the most significant ice-shelf break-up in the region is documented on the Landsat TM image of 29 February 1988 (Fig. 4), indicating that a calving event affected about $2 / 3$ of the Larsen Inlet. Unfortunately this area lies within the image corner, showing only the southernmost tip of Sobral Peninsula, making it impossible to draw the precise retreat line inside the inlet; therefore the ice front position here was only estimated, as indicated by a dotted line on Figure 2.

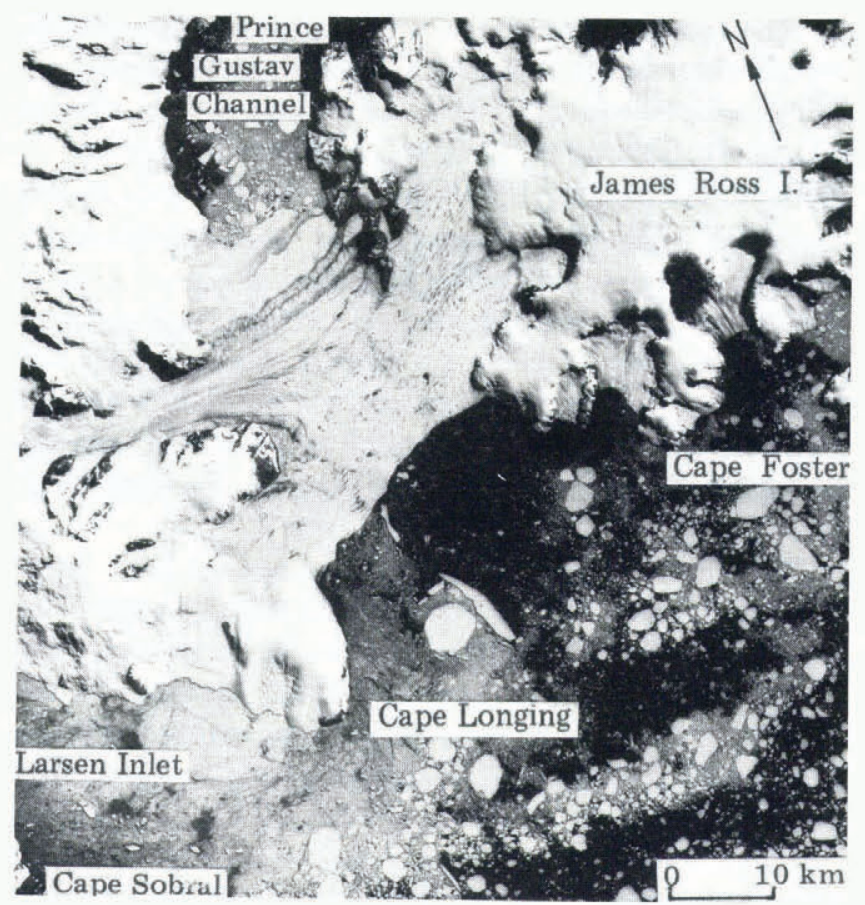

Fig. 4. Bottom left corner of Landsat TM (ID 4205412162-4) of 29 February 1988, indicating the Larsen Inlet break-up event. The ice front positions in Prince Gustav Channel are clearly defined. Note also the presence of meltwater (Reproduced by permission of EOSAT).

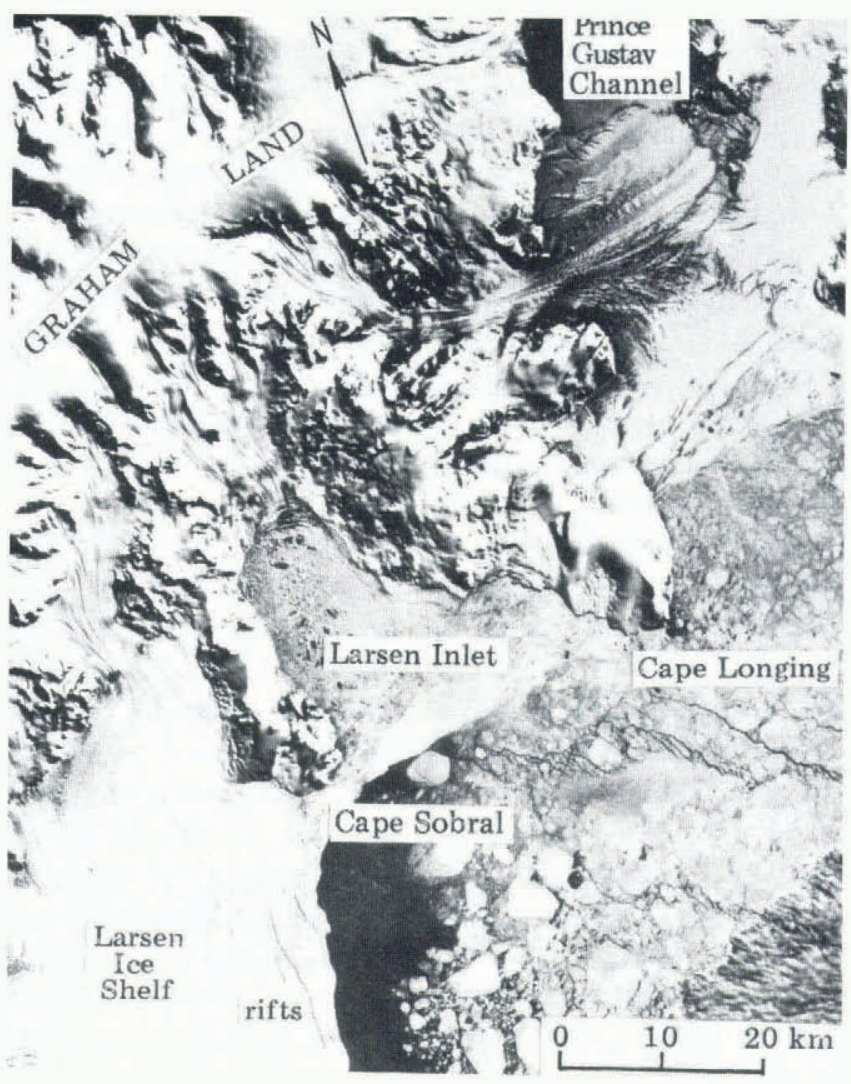

Fig. 5. Landsat TM image (ID 42669-12303) of 5 November 1989. Icebergs and sea ice may be observed within the Larsen Inlet. Note the rifts south of Sobral Peninsula (Reproduced by permission of EOSAT). 
The Landsat TM image of 5 November 1989 (Fig. 5) reveals that the disintegration process within the Larsen Inlet was continuing towards the grounding line: around $60 \mathrm{~km}^{2}$ are estimated to have calved-off during the 20 month time interval. It is important to note than during the period 1986-89 (3.7 years) the ice shelf has decreased by approximately $550 \mathrm{~km}^{2}$, i.e. almost the same area as during the 10.5 years of the period $1975-86$, indicating an accelerated rate of break-up within this region in the recent past. The ice shelf area between Seal Nunataks and Cape Longing (Fig. 2), calculated to be $\sim 3400 \mathrm{~km}^{2}$, has decreased by more than $30 \%$ during the interval 1975 89.

The 1989 image (Fig. 5) shows several N-S longitudinal rifts, almost parallel to the ice front, extending up to $10 \mathrm{~km}$ south of Sobral Peninsula, suggesting that disintegration processes would probably continue in this area; such disintegration has been confirmed by measurements of the ice shelf front positions carried out in the field during November 1991. From a traverse line Larsen Nunatak to Sobral Peninsula, positions of the ice front were determined at three locations, marked by the solid line segments in Figure 2. Since the rifts shown on the 1989 image were not detected either by field observations or by air reconnaissance, except immediately north of Lindenberg Island, we assume that the calving occurred along these rifts sometime after November 1989. The 1991 ice front position was therefore plotted beyond the position of the former rifts as shown by the dotted line on Figure 2. The 1991 field data compared with the 1989 ice front line give a maximum retreat of $2.5 \mathrm{~km} \mathrm{a}^{-1}$ in the northern part, near Sobral Peninsula, decreasing to about $1 \mathrm{~km} \mathrm{a}^{-1}$ near Lindenberg Island. Field measurements of the ice front position between Lindenberg and Christensen Islands indicate that almost no retreat has occurred within this part since 1986. Surface velocities along the transect Larsen Nunatak-Sobral Peninsula were obtained by optical survey at 14 sites, with a measuring interval of 15 days, giving an ice shelf movement of $\sim 220 \mathrm{~m} \mathrm{a}^{-1}$ north of Larsen Nunatak, decreasing northwards to $\sim 165 \mathrm{~m} \mathrm{a}^{-1}$ south of Sobral Peninsula. The ice thickness measured with a monopulse ice radar along the same profile, by contrast, is increasing northwards from $180 \mathrm{~m}$ to $250 \mathrm{~m}$.

A small remnant of the Larsen Ice Shelf within Prince Gustav Channel, between James Ross Island and Graham Land (Fig. 1), is the most northerly floating ice shelf in the Southern Hemisphere (Swithinbank, 1988), lying just within the extreme climatic limit for ice shelves, which is the $-5^{\circ} \mathrm{C}$ mean annual isotherm at sea level (Reynolds, 1981); it is formed mostly by freezing of sea water (Reece, 1950), except in the area of the Sjögren Glacier Tongue (Fig. 6). This remaining thin shelf ice probably survives because of the sheltered channel environment. It has separated at Cape Longing from the rest of the Larsen Ice Shelf sometime between 1957-58 (Doake, 1982). More recent reduction of the ice shelf within the Prince Gustav Channel is documented on images of 1986, 1988 and 1989 (Figs 3, 4 and 5) and the north and south ice front positions drawn on Fig. 6 . This figure also shows the approximate 1957 north and 1969 south ice front limits obtained from the previously mentioned BAS topographic map. Almost no change has occurred at the southern end from 1969 until 1986,

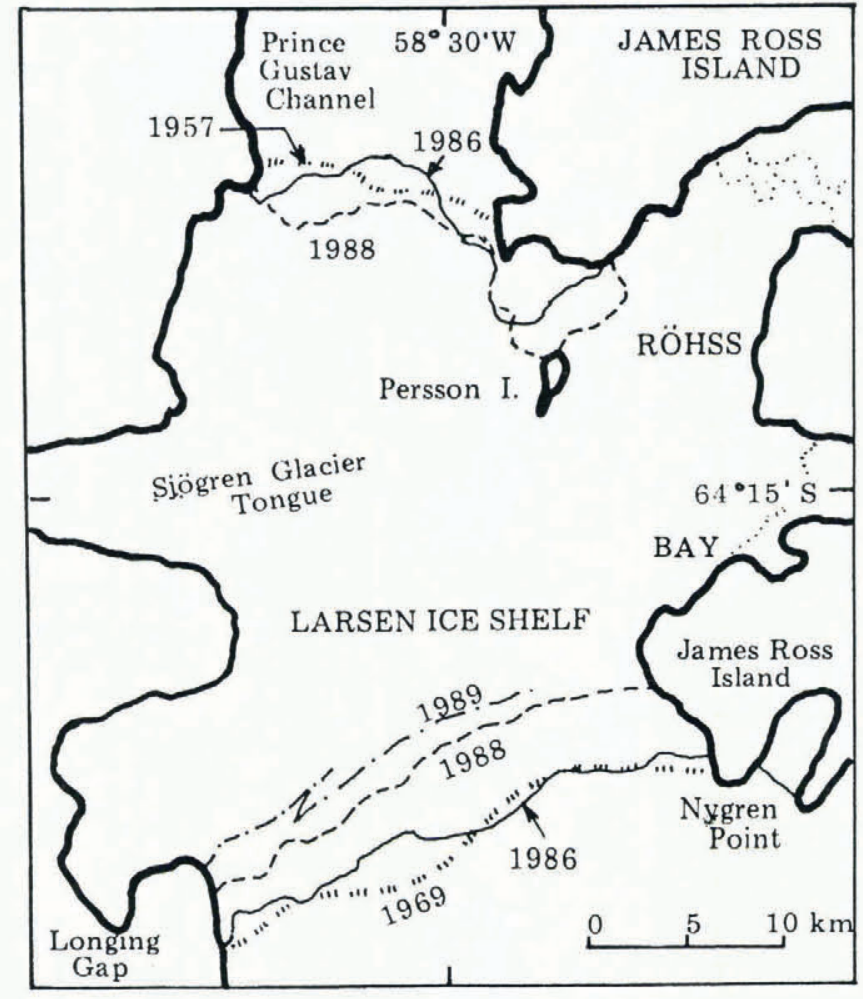

Fig. 6. Ice-shelf retreat within the Prince Gustav Channel based on 1986, 1988 and 1989 Landsat TM images and the BAS topographic map.

whereas during the interval 1986-88 the ice front retreated by $\sim 2 \mathrm{~km}$ along its southwestern part, and by $\sim 4 \mathrm{~km}$ along the northeastern half of the front. The 1989 position is inferred by an open lead paralleling the ice front, though the ice still remains attached to the shelf (Fig. 5). At the northern front of the shelf a considerable retreat also took place during 1986-88; but when comparing these positions with that of 1957, no significant variation is observed during almost 30 years, except north of Persson Island.

\section{DISCUSSION}

Ice shelves lying close to the climatic limit are sensitive to environmental changes. Their stability is affected by the increase in sea-water and air temperatures. Unfortunately there are no sea-temperature data available within this part of the Weddell Sea, but a warming trend occurring in this region is shown by the temperature records from Marambio Station located on Seymour Island, the closest to the ice shelf considered, and Esperanza Station, at the northern tip of Antarctic Peninsula. These stations have temperature data recorded since 1971 and 1953 respectively. Mean decadal temperatures computed for the last two decades indicate an increase of about $0.5^{\circ} \mathrm{C} /$ decade at both stations, in agreement with the Orcadas Station (South Orkney Islands) data (Hoffmann, 1991). The same author shows a temperature increase of $0.28^{\circ} \mathrm{C}$ / decade at Orcadas Station from 1930 onwards.

The expected increase in ablation and in the amount of meltwater on the ice shelf surface due to climatic 
warming was suggested to play an important role on fracture toughness and ice-shelf decay (Doake and Vaughan, 1991). That meltwater on the northern Larsen Ice Shelf is abundant, especially in warm summers, is known from personal field observations and has been cited by Mason (1950), Reece (1950) and Swithinbank (1988), among others. Meltwater is also seen on the Landsat TM images of 19 January 1988 (not shown) and 29 February 1988 (Fig. 4). These images, taken during a warm spell in the region between 1986 to 1989 (National Meteorological Service, unpublished) reveal the presence of many small lakes and ponds as well as numerous meltstreams following flow lines. These meltstreams may reach the seaward edge, mainly in the area north of Seal Nunataks.

The ice shelf within the Larsen Inlet and south of the Sobral Peninsula was also notorious for being heavily crevassed and rifted, as shown on satellite images and observed during recent field traverses. Thus the increased amount of meltwater could have enhanced the fracturing and rifting, being probably responsible for the continuous ice shelf reduction and the major 1986-88 break-up event.

\section{CONGLUSIONS}

The rapid and continuous recession of the northern end of the Larsen Ice Shelf, probably in response to the Antarctic Peninsula regional climatic warming, could be detected since 1975 onwards by satellite remote sensing. Results presented here also show the importance of continuing the monitoring of changes along the coastal areas of Antarctica with high-resolution satellite images, especially within this dynamic area where the response to regional or global change in climate may be easily detected.

\section{ACKNOWLEDGEMENTS}

The author would like to express his deep thanks to J. G.
Ferrigno and R.S. Williams, Jr of the U.S. Geological Survey for providing the 1978 and 1979 Landsat images.

\section{REFERENCES}

Doake, C. S. M. 1982. State of balance of the ice sheet in the Antarctic Peninsula. Ann. Glaciol., 3, 77-82.

Doake, C.S. M. and D. G. Vaughan. 1991. Rapid disintegration of the Wordie Ice Shelf in response to atmospheric warming. Nature, 350(6316), 328-330.

Ferrigno, J. G., R. S. Williams, Jr, B. K. Lucchitta and B. F. Molnia. 1990. Recent changes in the coastal regions of Antarctica documented by Landsat images. International Conference on the Role of Polar Regions in Global Change, June 11-15, 1990, University of Alaska Fairbanks. Abstracts, 24.

Hoffmann, J.A.J. 1991. De las variaciones de la temperatura del aire en la Argentina y estaciones de la zona subantártica adyacente, desde 1903 hasta 1989 inclusive. Primera Conferencia Latinoamericana sobre Geofísica, Geodesia e Investigación Espacial Antárticas, Buenos Aires, Argentina, Julio 30-Agosto 3, 1990. Actas, 160-168.

Koerner, R. M. 1964. Glaciological observations in Trinity Peninsula and the islands in Prince Gustav Channel, Graham Land, 1958-60. Br. Antarct. Surv. Sci. Rep. 42.

Mason, D. 1950. The Larsen shelf ice. 7. Glaciol., 1(8), 409-413.

Reece, A. 1950. The ice of Crown Prince Gustav Channel, Graham Land, Antarctica. J. Glaciol., 1(8), $404-409$.

Reynolds, J. M. 1981. The distribution of mean annual temperatures in the Antarctic Peninsula. Br. Antarct. Surv. Bull. 54, 123-133.

Swithinbank, C.W.M. 1988. Satellite image atlas of glaciers of the world. Antarctica. U.S. Geol. Surv. Prof. Pap. 1386-B.

The accuracy of references in the text and in this list is the responsibility of the author, to whom queries should be addressed. 